\title{
DESJUDICIALIZAÇÃO E ACESSO À JUSTIÇA ALÉM DOS TRIBUNAIS: PELA CONCEPÇÃO DE UM DEVIDO PROCESSO LEGAL EXTRAJUDICIAL ${ }^{1}$
}

\section{ACCESS TO JUSTICE BEYOND COURTS: TOWARDS A CONCEPT OF EXTRAJUDICIAL DUE PROCESS OF LAW}

\author{
"Fazer da interrupção um caminho novo. Fazer da queda um \\ passo de dança, do medo uma escada, do sono uma ponte, da \\ procura um encontro." (Fernando Sabino, O Encontro \\ Marcado)
}

Flávia Pereira Hill Doutora e mestre em Direito Processual pela UERJ. Professora Adjunta de Direito Processual Civil da UERJ (graduação, pós-graduação lato sensu, mestrado e doutorado). Pesquisadora visitante da Università degli Studi di Torino, Itália. Membro da Associazione Italiana di Diritto Comparato, do Instituto Brasileiro de Direito Processual, da Associação Brasileira de Editores Científicos e da Comissão de Mediação de Conflitos da OAB/RJ. Tabeliã. Rio de Janeiro/RJ. E-mail: flaviapereirahill@gmail.com

RESUMO: O artigo almeja analisar criticamente o fenômeno da desjudicialização da solução dos conflitos no Brasil, afirmando a importância de se cunhar a noção de devido processo legal extrajudicial. Parte-se da evolução do conceito de acesso à justiça que, nas últimas décadas, deixou de ser vista como sinônimo de acesso ao Poder Judiciário, conforme previsto no artigo $5^{\circ}$, inciso XXXV, da Constituição Federal de 1988, para abarcar a noção de Justiça Multiportas, preconizada no artigo 3º do Código de Processo Civil de 2015, e que mediante o compartilhamento do exercício da jurisdição entre diferentes núcleos decisórios.

\footnotetext{
${ }^{1}$ Artigo recebido em 29/08/2020 e aprovado em 15/12/2020.
} 
Entende-se que a desjudicialização deve resguardar as garantias fundamentais do processo, não importando em retrocesso garantístico. Para tanto, faz-se necessário cunhar a noção de devido processo legal extrajudicial, composto pelos seguintes elementos mínimos, que são abordados no texto: a) imparcialidade e independência; b) controle externo; c) publicidade; d) previsibilidade do procedimento; e) contraditório.

PALAVRAS-CHAVE: Desjudicialização; acesso à justiça; devido processo legal; imparcialidade; publicidade; previsibilidade do procedimento; contraditório.

ABSTRACT: The present study aims to critically analyze the new concept of access to justice beyond courts, in order to assert the importance of due process of law in this specific matter. The study compares the concept of access to justice in the Brazilian Constitution of 1988, centered in the role of the courts, and in the Brazilian Civil Procedure Code of 2015, which promotes the idea of multidoor courthouses. Access to justice beyond courts must observe procedural guarantees and fundamental rights, with no place for setbacks. Owing to this, the study elaborates the concept of extrajudicial due process of law, assembling five elements, which will be studied in the article: a) impartiality and independence; b) external control; c) publicity; d) predictability of proceedings; e) contradictory.

KEY WORDS: Justice beyond courts; access to justice; due process of law; impartiality; publicity; predictability of proceedings; contradictory.

\section{Do "acesso ao Judiciário" no século XX ao "acesso à justiça” no século XXI. Justiça Multiportas: realidade ou miragem?}

Ao tempo da promulgação da Constituição Federal de 1988, que marcou o período de redemocratização em nosso país, vivenciávamos diversos fatores que obstavam o acesso dos jurisdicionados brasileiros ao Poder $\mathrm{Judiciário}^{2}$, razão pela qual, com propriedade, o constituinte acabou por considerar, naquele contexto histórico, acesso à justiça como

\footnotetext{
${ }^{2}$ Discorremos sobre o tema com maior vagar em outro trabalho, ao qual ora remetemos o leitor. HILL, Flávia Pereira. Desjudicialização da Execução Civil: Reflexões sobre o Projeto de Lei No 6.204/2019. Revista Eletrônica de Direito Processual. Volume 21, número 3. Setembro-Dezembro de 2020. pp. 165-206.
} 
sinônimo de acesso ao Poder Judiciário. Essa concepção encontra-se gravada na redação do artigo $5^{\circ}$, inciso XXXV, da Constituição, ao prever que "a lei não excluirá da apreciação do Poder Judiciário lesão ou ameaça a direito".

No entanto, muito se passou nos mais de trinta anos que nos separam daquele momento histórico, a ponto de, hoje, nos ressentirmos precisamente do que poderíamos classificar como "efeitos colaterais" decorrentes da desejável vitória dos óbices ao acesso ao Poder Judiciário. O Relatório Justiça em Números publicado em 2020 pelo Conselho Nacional de Justiça nos revela uma taxa de congestionamento dos tribunais brasileiros da ordem de $68,5 \%{ }^{3}$.

De fato, tanto logramos destrancar o acesso ao Poder Judiciário que, na atualidade, verificamos o seu congestionamento justamente em razão da altíssima demanda (hiperjudicialização).

Esforçamo-nos, então, por cunhar mecanismos que mitiguem o tempo de duração dos processos judiciais, tais como, ad exemplum tantum, a improcedência liminar do pedido, o julgamento antecipado parcial do mérito, a estabilização da tutela provisória, os filtros recursais, o incidente de resolução de demandas repetitivas e tantos outros.

No entanto, para além de circunscrever os esforços ao gerenciamento dos processos judiciais, nos encontramos em um momento histórico que nos permite cunhar soluções extra muros, ou seja, para além dos limites do Poder Judiciário.

Se, de um lado, não se mostra defensável compactuar com a ideia de contenção do número de demandas - seja com o mágico, ilusório (e indesejável) desaparecimento por completo dos conflitos na sociedade, seja com a igualmente ilusória ideia de os litigantes não mais pretenderem ter os seus conflitos solucionados adequadamente -, pois representaria, em última análise, chancelar uma nefasta litigiosidade contida, incompatível com o Estado Democrático de Direito, de outro lado, somos convidados a construir, concretamente, a noção de Justiça Multiportas.

O termo multidoor courthouses, que deu origem, entre nós, à expressão "Justiça Multiportas", foi cunhado pelo Professor Frank Sander, na célebre Pound Conference, realizada em 1976 nos Estados Unidos, e pressupõe o remodelamento do papel dos tribunais,

3 CONSELHO NACIONAL DE JUSTIÇA. Justiça em números 2020. Disponível em https://www.cnj.jus.br/wp-content/uploads/2020/08/WEB-V3-Justi\%C3\%A7a-em-N\%C3\%BAmeros2020-atualizado-em-25-08-2020.pdf Consulta realizada em 05/10/2020. P. 112. 
deixando de ser apenas o local em que os processos são julgados para se tornar mais amplamente um dispute resolution center (centro de resolução de disputas), em que as partes são remetidas para o mecanismo mais adequado para a solução do conflito em que estejam envolvidas ${ }^{4}-5$.

Desde então, no Brasil, muito se propala, em tese, a adoção da Justiça Multiportas. No entanto, apenas reverberar o "slogan" infelizmente não possui o condão de concretamente alterar a configuração do nosso sistema de justiça, fortemente centrada no Poder Judiciário até os dias atuais.

Cabe, então, a pergunta: a Justiça Multiportas será, no Brasil, uma realidade ou apenas uma miragem?

Tornar a Justiça Multiportas uma realidade implica construir concreta e laboriosamente novas portas de acesso ao sistema de justiça como um todo, que se coloquem ao lado da porta de acesso ao Poder Judiciário, dentro da concepção de pluralismo decisório ou jurisdição compartilhada, expressões sabiamente cunhadas por Mancuso ${ }^{6}$. Sem esse esforço concreto, nos contentaremos com a Justiça Multiportas enquanto miragem, que muito se anuncia, mas que, ao se aproximar dela, o jurisdicionado descobre ser, na verdade, uma doce ilusão, tão envolvente quanto utópica.

Tornar a Justiça Multiportas uma realidade não consiste em tarefa simples nem tampouco simplória.

Mas o dado promissor é que o legislador pátrio já deu vários passos nesse sentido, a começar pela clara redação do artigo $3^{\circ}$ do Código de Processo Civil de 2015, ao dispor que "não se excluirá da apreciação jurisdicional ameaça ou lesão a direito", abandonando de vez a coincidência entre acesso à justiça e acesso ao Poder Judiciário, que justificadamente marcou a Constituição Federal de 1988, em razão do contexto histórico em que fora promulgada.

Especialmente nos últimos 16 anos, após a edição da Emenda Constitucional $n^{\circ}$ 45/2004, que criou o Conselho Nacional de Justiça, este órgão houve para si a tarefa de

\footnotetext{
${ }^{4}$ GOLDBERG, Stephen B. SANDER, Frank E. A. ROGERGS, Nancy H. COLE, Sarah Rudolph. Dispute Resolution. 4. Ed. Nova York: Aspen Publishers. 2003. p. 07.

${ }^{5}$ Tivemos a oportunidade de discorrer mais detidamente sobre o tema em outro trabalho, ao qual remetemos o leitor. HILL, Flávia Pereira. "Passado e futuro da mediação: perspectiva histórica e comparada". Revista de Processo. vol. 303/2020. pp. 479 - 502. Maio 2020.

${ }^{6}$ MANCUSO, Rodolfo de Camargo. A resolução dos conflitos e a função judicial no contemporâneo estado de Direito. 2. Ed. São Paulo: Revista dos Tribunais. 2013.
} 
construir concretamente a Justiça Multiportas em nosso país, a partir de várias iniciativas que fomentaram a tendência à desjudicialização da solução dos conflitos no Brasil, de modo a disponibilizar ao jurisdicionado o acesso a outras portas em nosso sistema de justiça, nas quais ele poderá ingressar para obter a providência almejada com igual (ou maior) efetividade.

O presente artigo almeja definir que a construção da Justiça Multiportas em um Estado Democrático de Direito deve estar alicerçada, em bases sólidas, na noção de um devido processo legal extrajudicial, com vistas a garantir que, com a desjudicialização, não haja déficit garantístico. Cada qual das portas que compõem a Justiça Multiportas agasalhará as garantias fundamentais do processo, que são conquistas democráticas da ciência processual, respeitadas, por certo, as peculiaridades inerentes a cada um dos mecanismos disponibilizados.

Conforme dissemos linhas antes, a construção da Justiça Multiportas não consiste em tarefa simples nem tampouco simplória, exigindo de todos nós variados esforços, mas decerto a reconfiguração do nosso sistema de justiça, mantido o patamar garantístico, propiciará a concretização de um acesso à justiça consentâneo com o exercício amadurecido da democracia no processo, passados mais de trinta anos de vigência da Constituição-cidadã.

Passemos a analisar sucintamente a noção de desjudicialização no Brasil para, a seguir, nos debruçarmos sobre os principais elementos que devem compor a noção de devido processo legal extrajudicial, guardados os limites de um artigo científico.

\section{A desjudicialização.}

A desjudicialização consiste no fenômeno segundo o qual litígios ou atos da vida civil que tradicionalmente dependeriam necessariamente da intervenção judicial para a sua solução passam a poder ser realizados perante agentes externos ao Poder Judiciário, que não fazem parte de seu quadro de servidores. Trata-se, em suma, da consecução do acesso à justiça fora do Poder Judiciário, ou seja, do acesso à justiça extra muros.

Até 2007, o legislador ensaiou alguns movimentos pontuais de desjudicialização, o que podemos exemplificar com a Lei Federal nº 6015/1973 (Lei dos Registros Públicos), a Lei Federal $n^{\circ} 8.951 / 1994$ (consignação em pagamento extrajudicial, com a inserção do $\S$ 
$1^{\circ}$ no art. 890 do CPC/73) e a Lei Federal n 9.514/1997 (alienação fiduciária em garantia de coisa imóvel), dentre outros.

No entanto, entendemos que o turning point ocorreu com a edição da Lei Federal $n^{\circ}$ 11.441, em 2007, que previu a possiblidade de que inventário, partilha, separação e divórcio consensuais fossem realizados através de escritura pública, em cartórios extrajudiciais de Notas. A novidade foi amplamente divulgada na mídia à época e formaram-se filas nas portas dos cartórios no primeiro dia útil subsequente. Foi a alta receptividade da sociedade a essa iniciativa que, a nosso ver, de um lado, deu novo fôlego à desjudicialização no terceiro milênio e, de outro, credenciou as serventias extrajudiciais como polo legítimo de prestação da jurisdição em seus contornos contemporâneos, conforme bem construído por Humberto Dalla ${ }^{7}$.

A criação do Conselho Nacional de Justiça, pela Emenda Constitucional no 45, em 2004, igualmente contribuiu para o incremento da desjudicialização, tendo em vista que, em diversas hipóteses, o fenômeno avançou através da edição de atos normativos oriundos do referido órgão de controle, conforme salientamos no item introdutório do presente trabalho.

Podemos exemplificar a evolução da desjudicialização com a possibilidade de alteração, diretamente no cartório de Registro Civil de Pessoas Naturais, de prenome e sexo no registro de nascimento em virtude de transexualidade (Provimento ${ }^{\circ}$ 73/2018 do CNJ), averbação da paternidade ou maternidade socioafetiva diretamente perante o cartório de Registro Civil de Pessoas Naturais (Provimento $n^{\circ}$ 83/2019 do CNJ) e retificação

\footnotetext{
7 “(...) o art. $3^{\circ}$ do NCPC, ao se referir a apreciação jurisdicional, vai além do Poder Judiciário e da resolução de controvérsias pela substitutividade. $\mathrm{O}$ dispositivo passa a permitir outras formas positivas de composição, pautadas no dever de cooperação das partes e envolvendo outros atores. Desse modo, a jurisdição, outrora exclusiva do Poder Judiciário, pode ser exercida por serventias extrajudiciais ou por câmaras comunitárias, centros ou mesmo conciliadores e mediadores extrajudiciais. (...) A jurisdição é essencialmente uma função estatal. Por isso, em momentos históricos diversos, desde a Antiguidade, passando pelas Idades Média, Moderna e chegando à contemporânea, o Estado, invariavelmente, chamou para si o monopólio da jurisdição, sistematizando-a, a partir de Luiz XIV. A atuação jurisdicional, então, era um poderoso mecanismo para assegurar o cumprimento das leis. No entanto, Leonardo Greco admite que a jurisdição não precisa ser, necessariamente, uma função estatal. É claro que não se pode simplesmente desatrelar a jurisdição do Estado, até porque, em maior ou menor grau, a dependência do Estado existe, principalmente para se alcançar o cumprimento da decisão não estatal. Por outro lado, podemos pensar no exercício dessa função por outros órgãos do Estado ou por agentes privados. Nesta ótica, percebe-se o fenômeno da desjudicialização enquanto ferramenta de racionalização da prestação jurisdicional e ajuste ao cenário contemporâneo, o que leva, necessariamente, à releitura, à atualização, ou ainda a um redimensionamento da garantia constitucional à luz dos princípios da efetividade e da adequação." PINHO, Humberto Dalla Bernardina de. "A releitura do princípio do acesso à justiça e o necessário redimensionamento da intervenção judicial na resolução dos conflitos na contemporaneidade". In Revista Jurídica Luso-brasileira. Ano 5. Número 3. 209. pp. 791- 830.
} 
extrajudicial de registro público (nova redação dada ao artigo 110, da Lei Federal $n^{\circ}$ 6.015/1973, pela Lei Federal nº 13.484/2017), dentre vários outros.

O Código de Processo Civil de 2015 contribuiu, por sua vez, para o avanço da desjudicialização, ao prever a usucapião extrajudicial (artigo 1071 do CPC/15 que inseriu o artigo 216-A na Lei Federal n 6.015/1973 e Resolução nº 65/2017 do CNJ), a consignação em pagamento extrajudicial (artigo 539, $\S 1^{\circ}$ a $4^{\circ}, \mathrm{CPC} / 2015$ ), a homologação do penhor legal extrajudicial (artigo 703, §2, $\mathrm{CPC} / 2015$ ), a divisão e demarcação de terras particulares extrajudicial (artigo 571, CPC/15), a dispensa de homologação, pelo Superior Tribunal de Justiça, de sentença estrangeira de separação e divórcio puros (artigo 961, §5º CPC/2015 e Provimento 53/2016 do CNJ), assim como ao deixar clara a importância das atividades extrajudiciais para o processo judicial, ao prever, ad exemplum tantum, a Ata Notarial como meio de prova típico (artigo 384, CPC/15), a possibilidade de averbação premonitória (artigo 828, CPC/15), o protesto de decisão judicial transitada em julgado (artigo 517, CPC/15), e a penhora de imóvel devidamente matriculado por termo nos autos (artigo 845, §1 ${ }^{\circ}, \mathrm{CPC} / 15$ ).

Entendemos que o fenômeno da desjudicialização, no Brasil, tem se desenvolvido em uma perspectiva bifronte, a saber:

\section{a) Jurisdição voluntária:}

Trata-se do que costumamos afirmar ser o habitat natural da desjudicialização, ou seja, o segmento em que a desjudicialização avança com menor resistência, visto que atrelada ao elemento do consenso, à ausência de litígio entre os interessados. Há, de fato, dezenas de procedimentos de jurisdição voluntária desjudicializados nos últimos quinze anos em nosso país.

\section{b) Jurisdição contenciosa:}

Identificamos que a desjudicialização dos procedimentos de jurisdição contenciosa, por seu turno, tem avançado nos últimos anos em duas frentes, notadamente:

b.1) Autocomposição: Consiste na adoção dos mecanismos de solução consensual dos litígios, valorizados pelo legislador no artigo $3^{\circ}$, $\S \S 2^{\circ}$ e $3^{\circ}$, do $\mathrm{CPC} / 2015$, dentre os quais sobressaem a mediação, a conciliação, a negociação direta e a negociação assistida. O CPC/2015, juntamente com a Lei Federal $n^{\circ} 13.140 / 2015$ e o Provimento 67/2018 formam o que se denomina marco legal da mediação no Brasil. Na autocomposição, o litígio é solucionado através da celebração de um acordo cunhado pelas próprias partes 
litigantes, com ou sem o auxílio de um terceiro imparcial e deve ser perquirida, nos dias atuais, preferencialmente à solução heterocompositiva.

b.2) Heterocomposição: Consiste no emprego de mecanismos em que há a substituição da vontade dos litigantes, mediante a imposição de uma solução por um terceiro imparcial que, no caso da desjudicialização, não integra o Poder Judiciário. O exemplo mais bem sucedido, no Brasil, de heterocomposição extrajudicial (adjudicação privada) consiste, sem sombra de dúvidas, na arbitragem, regulada pela Lei Federal nº 9.307/1996. A arbitragem encontra-se, a propósito, em franca expansão, o que se depreende a partir da edição da Lei Federal n ${ }^{\circ}$ 13.129/2015, que dentre outras medidas, autorizou expressamente que a Administração Pública submeta seus conflitos envolvendo direito patrimonial disponível à arbitragem, contanto que de direito e sujeita à publicidade.

Entendemos que um dos fatores que possibilitou a franca evolução da desjudicialização no Brasil consiste na reestruturação dos cartórios extrajudiciais, verificada nas últimas décadas. A edição da Lei Federal n n 6.015/1973 representou um primeiro passo, tendo em vista que regulamentou as atividades registrais prestadas por tais serventias.

No entanto, o principal elemento de mudança foi a promulgação da Constituição Federal de 1988 que, em seu artigo 236, previu que os serviços notariais e registrais são exercidos em caráter privado, por delegação do Poder Público, após aprovação em concurso público de provas e títulos, cabendo ao Poder Judiciário a sua fiscalização. Os cartórios extrajudiciais passam, assim, a ter à sua frente profissionais concursados, com vistas a resguardar a sua capacidade técnica.

A prestação de serviço público em caráter privado e a garantia de independência, contemplada no artigo 11 da Lei Federal $n^{\circ} 6.015 / 73$ e no artigo 28 da Lei Federal $n^{\circ}$ 8.935/94, permitem ao delegatário gerir a serventia de modo a desenvolver as atividades com isenção e maior eficiência, contratando produtos e serviços no mercado sem as restrições legais inerentes à contratação pelo Poder Público. De se consignar que os serviços extrajudiciais são custeados através de emolumentos (taxa) pagos diretamente pelos usuários e os investimentos na infraestrutura da serventia são realizados diretamente pelo delegatário com o produto de tal arrecadação. Esse contexto confere maior dinâmica à prestação dos serviços, inclusive no tocante à absorção das novas tecnologias. 


\section{O novo conceito de jurisdição na contemporaneidade.}

Conforme analisamos ao início do presente trabalho, migramos, no Brasil, da busca por garantir o acesso ao Judiciário para a busca por garantir mais amplamente o acesso à justiça. Isso revela mudanças profundas no conceito de jurisdição, que deixa de ser vista como monopólio do Poder Judiciário. O aspecto subjetivo deixa de ser um elemento indeclinável para a caracterização da jurisdição.

Isso porque a atividade não perde a sua essência exclusivamente em razão de ter sido praticada intra ou extra muros, ou seja, dentro ou fora do Poder Judiciário. O foco precisa estar, pois, na atividade desempenhada e não em quem a presta.

José Frederico Marques já reconhecia que "na sua evolução histórica, assumiram os notários a qualidade de juízes (judex chartularius, judex ordinarius) para a prática de atos de jurisdição voluntária". No entanto, o jurista frisava, refletindo a concepção de jurisdição que marcou o século XX, calcada no aspecto subjetivo, que a atividade extrajudicial "nem poderia considerar-se como função de jurisdição voluntária, porque esta compete exclusivamente a órgãos judiciários" $"$.

No entanto, no século XXI, sustentar que a atividade, ainda que congregue as características típicas da jurisdição, não possa assim ser considerada apenas em razão de não ser prestada pelo Poder Judiciário consiste em afirmação incompatível com os parâmetros atuais.

Precisamos, a nosso sentir, creditar à arbitragem o mérito por começar a revolver esse tradicional conceito, desafiando os processualistas a revê-lo.

No entanto, entendemos que a evolução prossegue, de modo que, assim como a prestação de jurisdição se dá através da arbitragem em especial, ela está presente também no fenômeno da desjudicialização em geral, tal qual vem sendo delineado pelo legislador nos últimos anos.

\footnotetext{
${ }^{8}$ MARQUES, José Frederico. Instituições de Direito Processual Civil. Vol. I. Campinas: Millennium 2000. pp. 315-318.
} 
A doutrina já reconhece que, nos métodos de solução consensual dos litígios, tais como mediação e conciliação, há prestação de jurisdição ${ }^{9}$. Ada Pellegrini, em seu último livro publicado, afirma expressamente que "a jurisdição compreende a justiça estatal, a justiça arbitral e a justiça consensual”. Como premissa central para tal afirmação, esclarece a autora que "o principal indicador" do novo conceito de jurisdição "é o de garantia do acesso à justiça, estatal ou não, e seu objetivo, o de pacificar com justiça"10.

Com efeito, a atividade, típica do Poder Judiciário, que passa a ser desempenhada, de forma crescente, pelos cartórios extrajudiciais em razão da desjudicialização ostenta os mesmos elementos informadores do novo conceito de jurisdição traçados acima.

As novas funções, que foram transferidas para os cartórios extrajudiciais em decorrência da desjudicialização, o foram precisamente com o escopo de garantir, em maior grau, o acesso à justiça nos dias atuais. Trata-se de movimento inerente à noção de Justiça Multiportas ${ }^{11}$, em que novos agentes são convocados a oferecer ao jurisdicionado outros mecanismos igualmente legítimos e adequados para a solução dos litígios (ou o exercício da jurisdição voluntária) e que se colocam ao lado da adjudicação estatal. Abrem-se vários possíveis caminhos para se chegar, no Estado Democrático de Direito contemporâneo, à pacificação com justiça.

Identificados novos núcleos de prestação da jurisdição legítimos, subverte-se a lógica que prevaleceu no século XX, segundo a qual o Poder Judiciário deveria ser visto como a prima ratio, e que contribuiu sobremaneira para a sua inegável sobrecarga. A noção da Justiça Multiportas reorganiza as prioridades do sistema de justiça, alçando, em boa hora, a consciência de que o Poder Judiciário, em uma democracia madura, deve ser visto como a ultima ratio $^{12}$. Não há que se pensar em violação à inafastabilidade do controle jurisdicional, tendo em vista que as portas do Poder Judiciário não são trancadas, em absoluto. Sendo

\footnotetext{
${ }^{9}$ GRINOVER, Ada Pellegrini. Ensaio sobre a processualidade, Fundamentos para uma nova teoria geral do processo. Brasília: Gazeta Jurídica.2018. p. 17.

${ }^{10}$ GRINOVER, Ada Pellegrini. Idem, p. 20.

${ }^{11}$ GOLDBERG, Stephen B. SANDER, Frank E. A. ROGERGS, Nancy H. COLE, Sarah Rudolph. Dispute Resolution. 4. Ed. Nova York: Aspen Publishers. 2003. p. 07.

${ }^{12}$ São precisas as palavras de José Joaquim Calmon de Passos, proferidas vinte anos atrás: "Esquecemo-nos de que o Direito é um medicamento com que procuramos restabelecer a saúde da convivência social (...) É a impotência dos homens, mediante suas instituições não-estatais, para prevenir e solucionar os conflitos oriundos de sua convivência, que impõe a utilização dos mecanismos jurídicos de que a tutela jurisdicional é a última e mais representativa expressão.” PASSOS, José Joaquim Calmon de. Direito, poder, justiça e processo. Rio de Janeiro: Forense. 2000.
} 
inviável o acesso aos mecanismos extrajudiciais, nada obsta a que o jurisdicionado recorra ao Poder Judiciário. Trata-se, apenas, de racionalizar o sistema de justiça e a entrega da prestação jurisdicional estatal.

Rompe com a lógica até então prevalecente e desafia a nossa cultura secular? Sim. Mas encontra óbice na Constituição e na legislação infraconstitucional vigente? Definitivamente não.

A nova conformação, decorrente do surgimento de novos polos de prestação da jurisdição, que se colocam ao lado do Poder Judiciário, todos credenciados a solucionar os litígios no Estado Democrático de Direito da contemporaneidade, vem sendo denominada "pluralismo decisório", "decisão compartilhada"13 ou "policentrismo processual"14.

Rodolfo de Camargo Mancuso destaca, com propriedade, que o Estado brasileiro precisa assumir "a contemporânea concepção da Jurisdição, identificada pela 'composição justa dos conflitos' e não mais, ou não necessariamente, pela solução adjudicada e imposta pelo Estado-juiz"15.

$\mathrm{O}$ acesso à justiça passa, assim, a evoluir lado a lado com o fenômeno da desjudicialização da solução dos conflitos, que tem como marca distintiva a possibilidade de que os litígios sejam solucionados por agentes que não integrem os quadros do Poder Judiciário.

Joel Dias Figueira Junior reconhece que:

“(...) a extrajudicialização como técnica resolutiva, inclusiva, participativa e eficiente se afigura como um alvissareiro e iluminado caminho sem volta que há muito o Brasil vem trilhando e reafirmando cada vez mais a sua exitosa prática" ${ }^{\prime 16}$.

\footnotetext{
${ }^{13}$ Rodolfo de Camargo Mancuso destaca que "o próprio legislador vem se mostrando sensível à tendência de Desjudicialização e até de privatização da resolução dos conflitos, como alternativa ao tradicional monopólio estatal da distribuição de justiça. Portanto, essa 'reserva de Justiça estatal', ao contrário do que se possa supor à primeira vista, não se extrai da letra nem do espírito do inciso XXXV do art. $5^{\circ} \mathrm{da} \mathrm{CF}$; ao contrário, ao afirmar que 'a lei não excluirá da apreciação do Poder Judiciário lesão ou ameaça a direito', esse texto não determina que todas as demandas devam ser encaminhadas à Justiça, mas sim que tal acesso deve operar como uma cláusula de reserva, de cunho residual, preordenada às controvérsias porventura insolúveis por auto ou heterocomposição, ou aquelas que, em razão da pessoa ou da matéria, devem merecer passagem judiciária" MANCUSO, Rodolfo de Camargo. A resolução dos conflitos e a função judicial no contemporâneo estado de Direito. 2. Ed. São Paulo: Revista dos Tribunais. 2013. p. 168.

14 OLIVEIRA, Daniela Olímpio de. "Uma releitura do princípio do acesso à justiça e a ideia da desjudicialização". Revista Eletrônica de Direito Processual. Volume 11. Pp. 67-98.

${ }^{15}$ MANCUSO, Rodolfo de Camargo. Op. Cit. p. 171.

16 FIGUEIRA JUNIOR, Joel Dias. "Desjudicialização da Execução Civil". Disponível em https://www.migalhas.com.br/depeso/330308/desjudicializacao-da-execucao-civil Consulta realizada em $08 / 07 / 2020$
} 
Novos desafios nos são dados. Contudo, estamos convencidos de que mais de trinta anos de vigência da Constituição-cidadão não podem ter sido em vão.

Nesse contexto, no nosso entender, as novas funções desempenhadas pelos cartórios extrajudiciais têm por finalidade potencializar o acesso à justiça na contemporaneidade.

No entanto, como vimos insistindo desde que começamos a pesquisar o tema, anos atrás, faz-se de todo necessário reiterar o compromisso com a observância das garantias fundamentais do processo nos procedimentos desjudicializados. Não se pode compactuar com eventual decréscimo garantístico em decorrência da desjudicialização.

Assim como Cândido Rangel Dinamarco já afirmava, com razão, ser necessário zelar pelo devido processo legal arbitral ${ }^{17}$, afigura-se imperioso, com igual empenho, moldar o que ora chamamos de devido processo legal extrajudicial.

Por tal razão, no próximo tópico, destacaremos alguns elementos distintivos, que necessariamente devem estar presentes, para que possamos cunhar a noção de devido processo legal extrajudicial.

\section{Devido processo legal extrajudicial.}

Enquadrar o exercício de determinada função como jurisdicional implica exigir, de forma correlata, no Estado Democrático de Direito, que o seu exercício observe fielmente o devido processo legal. Sendo assim, se as funções assumidas pelos cartórios extrajudiciais em decorrência da desjudicialização caracterizam-se como jurisdição, conforme desenvolvemos no item anterior do presente trabalho, então, consequentemente, mostra-se indispensável configurar o devido processo legal extrajudicial, que corresponde,

\footnotetext{
${ }^{17}$ Cândido Rangel Dinamarco leciona, com propriedade: "O primeiro pilar do presente estudo é, portanto, representado pela afirmação da plena incidência, sobre o processo arbitral, dos princípios e garantias constitucionais inerentes à segurança interna do sistema processual. Quando se pensa no acesso à justiça, que é a magna condensação de todas as garantias constitucionais do processo, hoje é imperioso incluir nesse pensamento as aberturas para a tutela jurisdicional pela via da arbitragem, como alternativas às vias estatais. Quando se pensa no contraditório e na ampla defesa, deve-se pensar na participação dos sujeitos processuais no processo estatal e no arbitral também. Quando enfim se pensa no due process of law como princípio tutelar da observância de todos os demais princípios, não se pode excluir o devido processo legal arbitral, como fonte de tutelas jurisdicionais justas e instrumento institucionalizado de pacificação social" DINAMARCO, Cândido Rangel. A nova era do processo civil. São Paulo: Malheiros. 2003. p. 30.
} 
precisamente, ao devido processo legal a ser observado nos cartórios extrajudiciais em razão do fenômeno da desjudicialização.

As maiores conquistas da atual fase da ciência processual - a que podemos chamar tanto de instrumentalismo como de formalismo valorativo, o que seria tema para outro trabalho - consistem justamente na consecução das garantias fundamentais do processo. Por isso, não se pode admitir que a desjudicialização, com vistas a potencializar o acesso à justiça através da Justiça Multiportas, compactue com eventual retrocesso garantístico, nem consinta em abrir mão precisamente das referidas garantias fundamentais, visto que representaria nefasto e intolerável retrocesso.

Sendo assim, embora não seja possível esgotar tema de tamanha envergadura nos estreitos limites de um artigo científico, estudaremos a concepção do devido processo legal extrajudicial sob cinco aspectos primordiais, a saber: (a) imparcialidade e independência dos agentes competentes; (b) controle externo; (c) publicidade; (d) previsibilidade do procedimento e (e) contraditório.

Preliminarmente, é necessário ter em mira quais são os novos núcleos decisórios, ou seja, quem são os novos agentes, indicados pelo legislador, para assumir as funções decorrentes do fenômeno da desjudicialização. Em outras palavras, afigura-se fundamental perguntar: para quem se está desjudicializando?

Esse aspecto se mostra relevante não apenas em razão da apuração da capacitação técnica de tais agentes para desempenhar funções até então exercidas pelo Poder Judiciário, mas também e especialmente em vista da verificação de sua legitimação em um Estado Democrático de Direito.

No Brasil, verifica-se que tanto o legislador, na edição das leis, quanto o Conselho Nacional de Justiça, na edição de resoluções e provimentos, têm atribuído aos delegatários de cartórios extrajudiciais a função de conduzir os procedimentos desjudicializados.

Diversos fatores se somam para que haja a convergência de várias disposições normativas em torno dos delegatários de cartórios extrajudiciais. O primeiro deles consiste na reconfiguração da carreira a partir do artigo 236 da Constituição Federal de 1988, que passou a exigir concurso público de provas e títulos, extinguindo de vez com a hereditariedade e condicionando a outorga da delegação a critérios técnicos objetivos lastreados no mérito, consoante expusemos anteriormente. 
A isso se acrescenta o soerguimento de todo um regime jurídico que rege tal carreira, composto por diversas leis esparsas, dentre as quais sobressaem a Lei Federal $n^{\circ}$ 6.015/73 e a Lei Federal no 8.935/94.

Ademais, as funções exercidas nas serventias extrajudiciais são fiscalizadas, em caráter permanente, pelo Poder Judiciário, tanto pela Corregedoria do Tribunal de Justiça local, quanto pelo Conselho Nacional de Justiça. A fiscalização pelo Poder Judiciário, que goza da confiança do jurisdicionado e que tradicionalmente exerce papel de centralidade no sistema de justiça brasileiro, consiste em importante fator para que logremos progredir paulatinamente na implantação da Justiça Multiportas, de modo a harmonizar tradição e evolução.

Sendo assim, a desjudicialização se desenvolve, em nosso país, em um ponto de convergência entre os ramos do Direito Notarial e Registral e do Direito Processual, ambos interpretados e aplicados à luz da Constituição Federal de 1988.

Portanto, é preciso conhecer e aplicar os institutos de Direito Notarial e Registral e as premissas que regem o regime jurídico dos delegatários das serventias extrajudiciais, que muito contribuirão para que verifiquemos ser não apenas desejável, mas plenamente viável, erigir os elementos essenciais de um devido processo legal extrajudicial.

Em grande parte, veremos não ser necessário iniciar a edificação do zero, pois dispomos de uma fundação sólida, escorada na Constituição Federal de 1988 e no regime jurídico que norteia a atuação dos delegatários de cartórios extrajudiciais.

Falar, pois, em devido processo legal extrajudicial em nosso ordenamento jurídico demanda a transposição de técnicas entre os dois ramos do Direito e o necessário e salutar diálogo entre as fontes, como veremos sucintamente nas linhas que se seguem.

\subsection{Imparcialidade e independência}

O primeiro passo para erigir a concepção de devido processo legal extrajudicial consiste em verificar se o agente que conduz e preside o procedimento congrega as características mínimas que atestam a sua legitimação e confiabilidade, segundo os parâmetros constitucionais. Para tanto, sobressaem as necessárias imparcialidade e independência de tais agentes. 
Em um Estado Democrático de Direito, a transferência ou o compartilhamento da função jurisdicional entre diferentes núcleos decisórios pressupõe que todos eles sejam imparciais e independentes. Por conseguinte, se, porventura, o legislador venha a desjudicializar determinado procedimento, elegendo, para tanto, um agente que não ostente tais características, entendemos que haverá manifesta inconstitucionalidade. Esse é, a propósito, um ponto sensível dos Projetos de Lei que preveem a desjudicialização da execução fiscal (Projetos de Lei n ${ }^{\text {os }} 2412 / 2007,5080 / 2009$ e PL 4257/2019), que passaria a ser conduzida pelos órgãos de assistência jurídica do Poder Público - especialmente a Procuradoria da Fazenda Nacional - e, em última análise, portanto, pelo próprio credor ${ }^{18}{ }_{-}{ }^{19}$ 20

No sentido propugnado neste trabalho, Leonardo Greco pontua, com propriedade, que "a jurisdição é exercida por órgãos independentes e imparciais, o que não significa, necessariamente, que ela deva ser exercida por juízes". Prossegue o autor destacando que "a imparcialidade lato sensu, abrangendo a independência e a imparcialidade stricto sensu, é uma nota característica e essencial da jurisdição, seja a jurisdição exercida por um órgão público, seja privada" ${ }^{21}$.

\footnotetext{
${ }^{18}$ HILL, Flávia Pereira. "Considerações sobre a desjudicialização da execução fiscal". Lições do isolamento: reflexões sobre Direito Processual em tempos de pandemia. Rio de Janeiro: Edição do autor. 2020. pp. 111122.

19“"Enquanto a Administração tributária brasileira continuar a inspirar-se mais no princípio da mais rigorosa obediência hierárquica do que no da legalidade, a única esperança de preservação das liberdades e dos direitos fundamentais dos cidadãos continuará a ser o Poder Judiciário, devendo ser repudiadas todas as tentativas de imposição aos contribuintes de atos coativos pela Administração Pública". GRECO, Leonardo. "As garantias fundamentais do processo na execução fiscal”. In LOPES, João Batista. CUNHA, Leonardo José Carneiro da (coords). Execução Civil (aspectos polêmicos). São Paulo: Dialética. 2005. Em outra sede, pontua o autor: "Assim, as resistências que certamente serão opostas a esse projeto de execução fiscal-administrativa tendem a convergir para a falta de imparcialidade dos funcionários por ela responsáveis. Quando se afirma, portanto, que a jurisdição é normalmente exercida por um órgão estatal, não se pretende excluir do seu conceito os casos em que essa função é exercida por quem não é juiz, por leigos temporariamente investidos no exercício da jurisdição, desde que garantidas a imparcialidade em sentido estrito e a independência". GRECO, Leonardo. Instituições de Direito Processual Civil. Vol. 1. Op. cit. p. 73.

${ }^{20}$ Diego Cantoario pontua: "Uma questão contundente é saber se o funcionário do fisco possui independência suficiente para realizar tais atos constrição, como previstos no projeto. Como já foi visto, no contencioso, administrativo europeu, a autoridade administrativa possui maior independência, até mesmo em razão da contribuição da Corte Europeia de Direitos Humanos para o avanço das relações Estado-cidadão. Situação diferente é a encontrada no Brasil, e nos países de cultura ibérica em geral, onde prevalece uma relação hierárquica entre os funcionários da Administração Pública". CANTOARIO, Diego Martinez Fervenza. "Considerações sobre o Projeto de Lei 5080/2009 - A nova lei de execução fiscal". Revista Tributária e de finanças públicas. Ano 18. Número 91. Março-abril 2010. pp. 11-42.

${ }^{21}$ GRECO, Leonardo. Instituições de Processo Civil. Vol. 1. Rio de Janeiro: GEN Forense. 2015. p. 70.
} 
O autor coroa o seu conceito de jurisdição na contemporaneidade erigindo como suas "duas características essenciais": (a) imparcialidade em sentido lato dos responsáveis pelo seu exercício; e (b) finalidade de tutelar interesses particulares ${ }^{22}$.

De se consignar que os registradores e tabeliães, a quem o legislador vem confiando papel de destaque na desjudicialização, são profissionais do Direito aos quais é imposto o dever de atuar com imparcialidade, razão pela qual o artigo 15 da Lei Federal no 6.015/73 e o artigo 27 da Lei Federal n ${ }^{\circ}$ 8.935/1994 coerentemente vedam que o notário e o registrador pratiquem, pessoalmente, qualquer ato de seu interesse, ou de interesse de seu cônjuge ou de parentes, na linha reta, ou na colateral, consanguíneos ou afins, até o terceiro grau.

Cabe aos delegatários atuar com imparcialidade, dispensando tratamento equidistante e isonômico a todos os sujeitos envolvidos e não tendo qualquer interesse na prática dos atos extrajudiciais que lhes são requeridos pelos usuários. Os delegatários não defendem nem patrocinam os interesses de nenhum dos sujeitos interessados na prática do ato extrajudicial, cabendo-lhes exclusivamente zelar para que, observados todos os parâmetros legais, possa o ato ser praticado regular, válida e eficazmente ${ }^{23}$.

De igual sorte, os delegatários das serventias extrajudiciais gozam de independência na sua atuação profissional em relação a qualquer sujeito, órgão ou instituição, não estando vinculados a nenhum condicionamento de ordem política, econômica ou administrativa ${ }^{24}, \mathrm{o}$ que deflui do artigo 28 da Lei Federal n 8.935/94. Portanto, tais profissionais devem pautar toda a sua atuação tendo como norte o atributo ora em análise, livres de pressões externas, não sendo, portanto, uma peculiaridade ou novidade em sua atuação em decorrência da desjudicialização.

Por exercer atividade técnica (artigo $1^{\circ}$, da Lei Federal $\left.n^{\circ} 8.935 / 94\right)$ e consistir em profissionais do direito (artigo $3^{\circ}$ da Lei Federal $n^{\circ}$ 8.935/94), os delegatários estão submetidos exclusivamente ao ordenamento jurídico.

A garantia de independência é de capital importância, a fim de criar condições para que os delegatários, enquanto profissionais técnicos, possam pautar o exercício de suas atribuições exclusivamente com fulcro nas leis e atos normativos aplicáveis. Tanto assim

\footnotetext{
${ }^{22}$ GRECO, Leonardo. Instituições... Op. cit. p. 75

${ }^{23}$ LOUREIRO, Luiz Guilherme. Registros Públicos. Teoria e Prática. 3. Ed. São Paulo: GEN Método. 2012. P. 533.

${ }^{24}$ LOUREIRO, Luiz Guilherme. Registros Públicos. Op. cit pp. 03 e 533.
} 
que lhes compete exercer a qualificação registral dos mandados judiciais e títulos emitidos pelo Poder Público, de modo a aferir o preenchimento dos requisitos formais previstos em lei como pressuposto para a prática do ato extrajudicial pretendido ${ }^{25}{ }_{-26}$.

A independência abarca o gerenciamento administrativo e financeiro da serventia extrajudicial, cabendo ao delegatário recrutar e contratar os seus prepostos (escreventes e auxiliares de cartório) (artigo 20, da Lei Federal nº 8.935/94), escolher o local onde instalará a serventia e guarnecê-la com o aparato necessário para exercer as atividades com eficiência.

As garantias de imparcialidade e independência são fundamentais para resguardar, com a desjudicialização, o mesmo patamar garantístico oferecido com a jurisdição estatal. Atribuir a condução dos procedimentos extrajudiciais a agentes que não gozem de independência e imparcialidade ilide toda a concepção de devido processo legal extrajudicial. Esse ponto nos conduz a receber com certo grau de preocupação a noção da desjudicialização fundada em procedimentos conduzidos por particulares, que não gozam de tais garantias e não estão jungidos a tais deveres, especialmente neste momento histórico, em que ainda estamos sedimentando a desjudicialização em nosso país.

\subsection{Controle Externo}

O segundo elemento a ser considerado na concepção do devido processo legal extrajudicial consiste no exercício de controle externo sobre a atuação dos novos núcleos decisórios. Sobressai a importância de que as funções que são transferidas (ou compartilhadas) do Poder Judiciário para outros agentes sejam fiscalizadas por um órgão externo, a fim de conferir transparência e garantir o seu exercício em consonância com os ditames do regime democrático e com o devido processo legal extrajudicial.

Por tal razão, causam-nos preocupação sugestões de desjudicialização que importem na assunção das funções correlatas por categorias profissionais ${ }^{27}$, que seriam fiscalizadas exclusivamente por seus próprios órgãos de classe.

\footnotetext{
${ }^{25}$ LOUREIRO, Luiz Guilherme. Registros Públicos. Op. Cit. P. 03.

${ }^{26}$ CENEVIVA, Walter. Op. Cit. P. 30.

${ }^{27}$ A respeito da nossa visão quanto à atuação dos advogados como agentes de execução, vide: HILL, Flávia Pereira. "O procedimento extrajudicial pré-executivo (Pepex): reflexões sobre o modelo português, em busca da efetividade da execução no Brasil”. In MEDEIROS NETO, Elias Marques de. RIBEIRO, Flávia Pereira. Reflexões sobre a Desjudicialização da Execução Civil. Curitiba: Juruá. 2020. pp. 305-322.
} 
A esse respeito, merece registro que os cartórios extrajudiciais são fiscalizados pelo Poder Judiciário, conforme expressamente previsto no artigo 236 da CF/1988. De fato, tanto o Tribunal de Justiça do respectivo Estado ou Distrito Federal quanto o Conselho Nacional de Justiça (artigo 48 do Regimento Interno do CNJ) fiscalizam, em caráter permanente, a atuação das serventias extrajudiciais.

O legislador pátrio tem optado por confiar as funções decorrentes da desjudicialização aos cartórios extrajudiciais, de modo que tais funções deixam de ser exercidas (exclusivamente) pelo Poder Judiciário, mas continuam sendo fiscalizadas por ele. Esse dado se mostra extremamente relevante, considerando-se que a hiperjudicialização, a nosso ver, demonstra que a sociedade brasileira confia no Poder Judiciário. Sendo assim, nada mais adequado, diante de nosso contexto político e cultural, do que o controle das funções decorrentes da desjudicialização ser realizado pelo Poder Judiciário.

Há, portanto, a desjudicialização na prestação de tais serviços, embora não haja propriamente a sua privatização, visto que continuam a ser considerados serviços públicos, ainda que prestados em caráter privado pelos cartórios extrajudiciais, e sem abrir mão da fiscalização pelo Estado-juiz.

Esse ponto é fundamental para lidar com as ponderações tecidas por Leonardo Greco, que salienta que a prestação da jurisdição pelo Estado é uma “característica histórica” a ser considerada. Em 2015, o autor preconizava:

\begin{abstract}
"Será que a História vai confirmar a evolução no sentido da desestatização da jurisdição? Eu pessoalmente acredito que sim, porque, a rigor, mesmo antes da formação do Estado, todos os povos juridicamente organizados instituíram os seus órgãos jurisdicionais como a exigência própria da vida em sociedade. (...) o Estado deve facilitar que a sociedade espontaneamente ou por indução de uma política pública planejada, venha a instituir os seus próprios mecanismos de exercício da jurisdição, criando as condições necessárias à coordenação da sua atuação com a dos órgãos estatais. Assim, ainda não se pode desligar totalmente o conceito de jurisdição de uma função tipicamente estatal, ou preponderantemente estatal, porque, entre nós, ela ainda o é, embora essa não me pareça a sua característica essencial." 28
\end{abstract}

De fato, o regime híbrido que vem sendo instituído pelo legislador e que marca a paulatina evolução da desjudicialização no Brasil, através da qual as funções decorrentes da

\footnotetext{
${ }^{28}$ GRECO, Leonardo. Instituições... Op. cit. p. 70.
} 
desjudicialização continuam sendo consideradas serviço público, agora prestado eminentemente por serventias extrajudiciais, mantendo-se a fiscalização do Poder Público, acaba por compatibilizar, de um lado, um certo grau de estatalidade exigido, até o momento, em virtude dos fatores históricos e culturais antes apontados, e, de outro, um maior potencial de eficiência e dinâmica em sua prestação, visto que prestado em caráter privado.

Ainda no tocante ao salutar controle externo, merece registro que, assim como as funções dos cartórios extrajudiciais vêm mudando em razão da desjudicialização, colocandoos como um dos protagonistas do sistema de justiça no século XXI em nosso país, de igual forma é de todo recomendável que o perfil da fiscalização exercida pelas Corregedorias dos tribunais locais e da Corregedoria Nacional de Justiça igualmente se adapte a essa nova realidade.

Além da conduta sancionatória e repressiva, voltada a atuar a posteriori, afigura-se de todo consentânea com a necessária cooperação entre as esferas judicial e extrajudicial no contexto da desjudicialização a fiscalização preventiva e construtiva, voltada a, mediante troca perene de impressões, experiências e dificuldades de parte a parte, permitir sejam prestados esclarecimentos e sejam cunhadas, conjuntamente, as formas mais adequadas de desenvolver as atividades extrajudiciais, especialmente no caso da assunção de novas funções extrajudiciais em decorrência da desjudicialização, que implica reformulações significativas na praxe cartorária. Cuida-se, pois, de uma fiscalização prospectiva e com caráter instrutivo e construtivo. Essa perspectiva da fiscalização passa pela noção, desenvolvida ao longo do presente estudo, de que a administração da justiça, na atualidade, é compartilhada por vários agentes, incluindo os delegatários dos cartórios extrajudiciais, e que a colaboração entre as Corregedorias e tais serventias, de forma construtiva, ensejará ganhos em efetividade e eficiência e, por conseguinte, resultará em maior grau de satisfação por parte do jurisdicionado, com redução do dispêndio de tempo e recursos ${ }^{29}$.

\footnotetext{
${ }^{29}$ Em outra sede, discorremos sobre a importância do incremento da colaboração entre as esferas judicial e extrajudicial em torno do que chamamos de "triplo C": cooperação, complementaridade e coordenação, que deve nortear a atuação de todos os núcleos decisórios no atual sistema de justiça e pode contribuir significativamente para incrementar a efetividade na prestação jurisdicional nos dias atuais. HILL, Flávia Pereira. "A desjudicialização e o necessário incremento da cooperação entre as esferas judicial e extrajudicial" In: ALVES, Lucelia de Sena. SOARES, Carlos Henrique. FARIA, Gustavo de Castro. BORGES, Fernanda Gomes e Souza (Orgs). 4 anos de vigência do Código de Processo Civil de 2015.1 ed. Belo Horizonte: D’Plácido, 2020, v.1, pp. 173-204.
} 


\subsection{Publicidade}

O terceiro elemento que nos parece relevante consiste na garantia de publicidade como regra. Forçoso convir que a arbitragem e a mediação, por suas peculiaridades, pressupõem o sigilo e a confidencialidade. Contudo, o mesmo não se pode afirmar a respeito do grande contingente de procedimentos que vêm sendo desjudicializados para os cartórios extrajudiciais.

A manutenção da publicidade favorece a transparência e o controle social da higidez da atuação dos novos núcleos decisórios, prestigiando o interesse público subjacente à prestação jurisdicional.

Com efeito, a atuação dos cartórios extrajudiciais tradicionalmente já se pauta pela publicidade como regra ${ }^{30}$ (artigo 16 e seguintes da Lei Federal $n^{\circ}$ 6.015/1973 e artigo $1^{\circ}$ da Lei Federal n 8935/1994), cabendo-lhes prestar informações de seus atos e lavrar certidão, independentemente da indicação de motivos pelo requerente, inclusive para fins estatísticos, de interesse nacional ou de fiscalização pública $^{31}$, o que se coaduna com a premissa ora traçada.

\subsection{Previsibilidade do procedimento}

O quarto elemento que compõe a noção de devido processo legal extrajudicial consiste na relevância da previsibilidade do procedimento para o Estado Democrático de Direito, o que não pode ser descurado na desjudicialização. Faz-se necessário que o jurisdicionado conheça previamente o procedimento previsto em lei, tanto como indispensável balizamento para a atuação do agente que preside o procedimento e contenção de eventuais excessos, quanto como forma de nortear a escolha de qual mecanismo de solução de conflitos o jurisdicionado prefere se valer.

Trata-se da atenção à forma na exata medida em que necessária para alcançar os escopos do processo, em especial a sua efetividade, evitando-se a chancela de um verdadeiro "processo kafkiano".

\footnotetext{
${ }^{30}$ LOUREIRO, Luiz Guilherme. Op. cit. pp. 38-41.

${ }^{31}$ CENEVIVA, Walter. Lei dos Registros Públicos Comentada. 15. Ed. São Paulo: Saraiva. 2002. pp. 35-36.
} 
José Roberto dos Santos Bedaque destaca, com razão, que:

“(...) a análise do processo pelo ângulo da técnica preordenada à realização de direitos é complementada pela visão política desse fenômeno, segundo a qual é ele garantia da liberdade, dos bens e da própria vida do cidadão" 32 .

Carlos Alberto Alvaro de Oliveira, por sua vez, ressalta que a organização da atividade jurisdicional consiste no "efetivo primeiro passo na estrada da coincidência entre autoridade e justiça" e prossegue salientando que "o processo não pode prescindir de um mínimo de organização, sendo inconcebível qualquer tentativa de informalizá-lo totalmente" $" 33$.

Sendo assim, o prévio conhecimento do procedimento a ser observado em cada hipótese em que haja a desjudicialização não se mostra um elemento secundário, mas fundamental e inerente ao conceito de devido processo legal extrajudicial que almejamos cunhar.

Ada Pellegrini Grinover reconhece que, na atualidade, o procedimento ganha especial importância, sendo autorizado afirmar que "a tutela processual adequada só pode ser obtida por intermédio do procedimento adequado" 34 .

Não podemos nos furtar de reproduzir a seguinte lição da referida autora:

"Eis mais uma vez destacada a relevância do procedimento, que de mera ordenação de atos passa a ser instrumento do instrumento processo, cioso das garantias do devido processo legal e teleologicamente voltado à obtenção da tutela adequada" 35 .

\footnotetext{
${ }^{32}$ Esclarece José Roberto dos Santos Bedaque que "Para alcançar esse resultado [atuação coercitiva da regra substancial e a pacificação dos litígios] a jurisdição vale-se de um método, ou seja, de um caminho, de um modo de proceder, regulado por normas de conduta predeterminadas. (...) A análise do processo pelo ângulo da técnica preordenada à realização de direitos é complementada pela visão política desse fenômeno, segundo a qual é ele garantia da liberdade, dos bens e da própria vida do cidadão. Na medida em que não há como conceber a sociedade sem conflito entre seus membros, impossível admitir o Estado Democrático de Direito sem o devido processo legal". BEDAQUE, José Roberto dos Santos. Efetividade do processo e técnica processual. São Paulo: Malheiros. 2006. pp. 41-42.

${ }^{33}$ OLIVEIRA, Carlos Alberto Alvaro de. Do formalismo no processo civil. São Paulo: Saraiva. 2003. pp. 108109.

${ }^{34}$ GRINOVER, Ada Pellegrini. Op. cit. p. 16.

${ }^{35}$ Idem, p. 17.
} 
Acrescente-se que Barbosa Moreira constata, com sua peculiar lucidez, que não se deve descurar do tecnicismo mínimo, tendo em vista que "a técnica bem aplicada pode constituir instrumento precioso a serviço da própria efetividade" 36.

Verifica-se que, de fato, a desjudicialização tem sido acompanhada, até aqui, da definição precisa do procedimento a ser observado.

\subsection{Contraditório}

Não poderíamos concluir os contornos mínimos do devido processo legal extrajudicial sem abordar, ainda que sucintamente, a importância do contraditório para o exercício da jurisdição na contemporaneidade ${ }^{37}$. Com efeito, a garantia do contraditório participativo consiste em uma das principais chancelas do processo como genuinamente democrático. Nada mais consentâneo com o Estado Democrático de Direito do que garantir aos sujeitos juridicamente interessados no desfecho do processo que dele participem.

Leonardo Greco pontua, com propriedade, que "hoje, o contraditório ganhou juma projeção humanitária muito grande, sendo, provavelmente, o princípio mais importante do processo" 38 .

A partir das lições de Leonardo Greco ${ }^{39}$, identificamos os seguintes corolários do contraditório participativo: (a) tempestiva cientificação de todos os sujeitos juridicamente interessados; (b) direito de apresentar alegações e provas; e (c) congruidade dos prazos, sendo conferido tempo razoável e suficiente para a prática dos atos processuais.

Se o contraditório é resguardado, inclusive, no processo administrativo (artigo $5^{\circ}$, LV, CF/1988 e artigo $2^{\circ}$ da Lei Federal no 9784/1999), em que não há a prestação de jurisdição, mais ainda se deve preservá-lo no processo extrajudicial, em que está presente o moderno conceito de jurisdição.

\footnotetext{
36 “'(...) efetividade e técnica não são valores contrastantes ou incompatíveis, que deem origem a preocupações reciprocamente excludentes, senão ao contrário, valores complementares, ambos os quais reclamam a nossa mais cuidadosa atenção". MOREIRA, José Carlos Barbosa. Temas de Direito Processual Civil. $\sigma^{a}$ série. Rio de Janeiro: Forense. 1997. P. 28.

37 “A garantia do contraditório está à base da regularidade do processo e da justiça das decisões. Trata-se de garantia fundamental de imparcialidade, legitimidade e correção de prestação estatal. Sem que o diálogo entre as partes anteceda ao pronunciamento estatal, a decisão corre o risco de ser unilateral, ilegítima e injusta: poderá ser um ato de autoridade, jamais de verdadeira justiça". GRINOVER, Ada Pellegrini. Op. cit. p. 23.

${ }^{38}$ GRECO, Leonardo. Op. Cit. P. 514.

${ }^{39}$ Idem, p. 513.
} 
Os procedimentos extrajudiciais devem necessariamente contemplar a cientificação de todos os interessados para que, querendo, possam se manifestar e apresentar as provas de suas alegações.

No caso da autocomposição, a participação ativa e contínua de todos os sujeitos interessados é a própria razão de ser do procedimento, sendo pressuposto inarredável para que se logre alcançar um acordo que reflita a sua genuína manifestação de vontade.

$\mathrm{Na}$ desjudicialização dos procedimentos de jurisdição voluntária, por sua vez, a ocorrência de impugnação por um dos interessados, tornando controvertida a questão objeto do processo extrajudicial, tende a tornar obrigatória a intervenção judicial. Nesse caso, fenecerá o requisito do consenso, previsto em lei como condição sine qua non da desjudicialização no segmento da jurisdição voluntária, como é o caso, por exemplo, de inventário, partilha (artigo 610, §1 ${ }^{\circ}, \mathrm{CPC} / 15$ ), separação, divórcio e extinção de união estável (artigo 733, CPC/15), divisão e demarcação de terras particulares (artigo 571, $\mathrm{CPC} / 15)$, dentre outros.

A manifestação do interessado pode, outrossim, fazer surgir fundada dúvida no delegatário da serventia extrajudicial sobre como proceder no caso, conduzindo-o a suscitar a "dúvida registral" ao juízo competente.

Merece registro que, no que tange à usucapião extrajudicial, faz-se necessária a apresentação de planta e memorial descritivo assinados por profissional legalmente habilitado e pelos titulares de direitos reais e de outros direitos registrados ou averbados na matrícula do imóvel usucapiendo e na matrícula dos imóveis confinantes. A obtenção da assinatura dos titulares de quaisquer direitos incidentes sobre o imóvel usucapiendo e confinantes é, a nosso ver, o requisito-chave para caracterizar a jurisdição voluntária e viabilizar a via extrajudicial.

O ponto central é que a redação original do $\S 2^{\circ}$ do artigo 216-A da Lei de Registros Públicos (trazida pela Lei Federal n ${ }^{\circ} 13.105 / 2015$ ) dispunha que, se a planta não contivesse a assinatura de qualquer um dos titulares de direitos reais e de outros direitos, o titular faltante seria notificado pelo registrador competente, pessoalmente ou pelo correio com aviso de recebimento, para manifestar seu consentimento expresso no prazo de 15 dias, interpretado o seu silêncio como discordância. Ocorre que a Lei Federal no 13.465/2017 
alterou a parte final do $\S 2^{\circ}$ do artigo 216-A da Lei de Registros Públicos para prever o oposto, ou seja, que o silêncio dos titulares será interpretado como concordância.

Não nos parece que a referida alteração legal viola, ipso facto, o princípio do contraditório, no entanto, afigura-se de todo recomendável, no nosso entendimento, que a notificação contenha expressamente o aviso de que o transcurso do prazo legal in albis importará em concordância tácita do interessado com a planta e o memorial descritivo apresentados, permitindo, assim, que seja dado prosseguimento ao procedimento de usucapião extrajudicial.

Transcendendo o âmbito da jurisdição voluntária, cumpre consignar que o Projeto de Lei $n^{\circ}$ 6204/2019, que trata da desjudicialização da execução civil, estabelece um regime escalonado de impugnação, que se desdobra em duas etapas, sendo a primeira extrajudicial e a segunda judicial. Nesse modelo, a irresignação do interessado é, primeiramente, examinada pelo delegatário da serventia extrajudicial (denominado agente de execução) e, caso seja rejeitada e o interessado mantenha a sua irresignação, a questão será submetida ao juízo competente para apreciação, em decisão irrecorrível (artigos 19 e 21 do Projeto de Lei). De igual sorte, o artigo 20 do mencionado projeto de lei preceitua que o delegatário de serventia extrajudicial poderá requerer ao juízo competente a aplicação de medidas de força e coerção, com vistas a efetivar as providências necessárias ao adequado desfecho da execução.

Esse modelo nos parece o mais acertado e consentâneo com os tempos atuais, tendo em vista que admite a formação de incidentes judiciais no bojo de procedimentos extrajudiciais, fortalecendo a indispensável cooperação entre as esferas judicial e extrajudicial no sistema de justiça contemporâneo e a correlata coordenação entre as duas esferas de atuação.

Com efeito, alcançamos, no moderno direito processual pátrio, em razão da desjudicialização, um novo patamar de processo sincrético, em que dispomos de um processo uno, composto por fases ou incidentes que se desenvolvem perante o cartório extrajudicial e perante o Poder Judiciário, ou seja, composto por fases extrajudiciais e judiciais, que se coordenam e se complementam, em prol da efetividade da prestação jurisdicional na contemporaneidade. 
Sendo assim, embora a desjudicialização abarque um conjunto de questões amplo e variado, faz-se necessário que, em todos os procedimentos, seja garantida a cientificação dos interessados e seja conferido prazo suficiente para que eles possam se manifestar.

Por tudo o que analisamos até aqui, constata-se que se faz necessário reordenar a Teoria Geral do Processo, adaptando-a às novas características do sistema de justiça na contemporaneidade, a fim de abarcar o fenômeno da desjudicialização, de modo a definir os contornos do contraditório, da ampla defesa e da segurança jurídica nesse segmento, assim como definir, dentre outros pontos, se e como podemos admitir intervenção de terceiros na esfera extrajudicial, prova emprestada entre as esferas judicial e extrajudicial e tantos outros temas correlatos. Ademais, cumpre realizar o necessário diálogo entre os regimes de Direito Processual e de Direito Notarial e Registral, visto que a desjudicialização tem se posicionado na zona de convergência entre os dois ramos do Direito. Sobre isso nos comprometemos, desde já, a futuramente nos deter em outro trabalho, visto que explorá-lo nesta sede transbordaria os limites originalmente propostos.

\section{Considerações finais}

A edição de leis, assim como as suas interpretação e aplicação, é inevitavelmente produto de seu contexto histórico. Sendo assim, não nos causa estranheza que o constituinte tenha identificado o acesso à justiça, em 1988, como acesso ao Poder Judiciário, diante dos severos óbices então encontrados ao recurso aos tribunais.

Se essa era a realidade ao tempo da edição da Constituição-cidadã, o mesmo não se pode afirmar dos dias atuais, em que, passados mais de 30 anos de sua vigência, experimentamos as desventuras de um Poder Judiciário assoberbado com mais de 80 milhões de ações e uma taxa de congestionamento preocupante, da ordem de 68,5\%, em razão do que chamamos de hiperjudicialização.

Embora o cenário seja, de fato, digno de atenção, entendemos que as últimas décadas, a par de criar os problemas, também cunhou as possíveis soluções. Experimentamos, de um lado, um incremento da difusão de informações no seio da sociedade, assim como a reconfiguração de algumas carreiras jurídicas, especialmente o fortalecimento da advocacia 
e a reestruturação dos cartórios extrajudiciais. A sociedade se mostra, pois, em condições de exercer uma participação mais madura no processo.

Nesse contexto, especialmente a partir de 2007, avança a desjudicialização em nosso país, através da edição de normas que transferem ou compartilham as funções até então desempenhadas exclusivamente pelo Poder Judiciário para novos núcleos decisórios, especialmente os cartórios extrajudiciais, embora a fiscalização perene de tais funções permaneça confiada aos tribunais locais e ao CNJ.

No entanto, a preocupação central do presente trabalho consiste em jogar luz sobre a importância de pensarmos a desjudicialização de forma ordenada e técnica, sem perder de vista que se trata de fenômeno atrelado ao funcionamento do sistema de justiça e que se situa em um ponto de convergência entre o Direito Notarial e Registral e o Direito Processual.

Em um Estado Democrático de Direito, isso significa dizer que a desjudicialização, para que se consolide como fenômeno apto a oferecer novos mecanismos adequados e democráticos, precisa propiciar o mesmo patamar garantístico experimentado no processo judicial (adjudicação estatal), não sem descurar, por óbvio, das peculiaridades do segmento extrajudicial. É preciso, pois, realizar o necessário diálogo entre fontes e a transposição de técnicas entre os dois ramos do Direito, sempre sob o pálio da Constituição Federal.

A noção de devido processo legal extrajudicial deve pautar os estudos sobre a desjudicialização, com vistas a permitir que as suas normas definidores sejam interpretadas e aplicadas à luz das garantias fundamentais do processo.

No atual estágio evolutivo da ciência processual e no patamar de expectativa do jurisdicionado com o sistema de justiça, não basta desjudicializar por desjudicializar. A preocupação com a imparcialidade e a independência dos novos núcleos decisórios, o seu controle externo, a publicidade, o contraditório e a previsibilidade do procedimento deve permear as nossas reflexões.

De igual modo, para que extraiamos todo o potencial que a desjudicialização nos oferece, é preciso haver a cooperação entre as esferas judicial e extrajudicial, assim como já existe, de forma crescente, a cooperação entre órgãos do Poder Judiciário (cooperação judiciária) e entre estes e os árbitros (carta arbitral).

Mostra-se, por fim, imperioso que a advocacia, que sói ser a ponte, por excelência, entre o jurisdicionado e os meandros de nosso sistema de justiça, conheça os novos 
mecanismos oferecidos pela desjudicialização, desbrave a seara extrajudicial e, assim, através do mapeamento da Justiça Multiportas, passe a oferecer ao seu cliente todos possíveis mecanismos adequados.

Verifica-se, pois, que, mais do que a previsão legal, o avanço da desjudicialização depende da mudança de cultura de todos os operadores do Direito, de modo a compreender e assimilar que novos agentes ingressem no centro da cena do sistema de justiça, com vistas, de um lado, a reduzir a dramática sobrecarga do Poder Judiciário, e, de outro, permitir que, zelando-se pelo devido processo legal extrajudicial, logremos oferecer ao jurisdicionado novos mecanismos aptos a solucionar, com efetividade, o crescente e multifacetado contingente de litígios que eclodem no seio da sociedade contemporânea.

Não podemos nos contentar, portanto, em reconhecer na desjudicialização simplesmente uma possibilidade de o jurisdicionado sair do Poder Judiciário e, assim, contribuir para a redução de sua sobrecarga. É preciso zelar para que a desjudicialização resguarde as garantias fundamentais do processo, que representam conquistas inegociáveis da ciência processual. Trata-se, pois, de permitir que o jurisdicionado saia do Poder Judiciário pela porta da frente, e, também por outras veredas, sem déficit garantístico, tenha acesso à ordem jurídica justa. Essa é a nossa missão.

\section{REFERÊNCIAS}

BEDAQUE, José Roberto dos Santos. Efetividade do processo e técnica processual. São Paulo: Malheiros. 2006.

CANTOARIO, Diego Martinez Fervenza. “Considerações sobre o Projeto de Lei 5080/2009 - A nova lei de execução fiscal”. Revista Tributária e de finanças públicas. Ano 18. Número 91. Março-abril 2010. pp. 11-42.

CARNEIRO, Paulo Cezar Pinheiro. "Acesso à justiça: Juizados Especiais Cíveis e Ação Civil Pública. Uma nova sistematização da Teoria Geral do Processo.” 2. Ed. Rio de Janeiro: Forense, 2000.

CENEVIVA, Walter. Lei dos Registros Públicos Comentada. 15. Ed. São Paulo: Saraiva. 2002. 
CONSELHO NACIONAL DE JUSTIÇA. Justiça em números 2020. Disponível em https://www.cnj.jus.br/wp-content/uploads/2020/08/WEB-V3-Justi\%C3\%A7a-emN\%C3\%BAmeros-2020-atualizado-em-25-08-2020.pdf Consulta realizada em 05/10/2020.

DIDIER JUNIOR, Fredie. Cooperação judiciária nacional: esboço de uma teoria para o Direito brasileiro (arts. 67-69, CPC). Salvador: Jus Podivm. 2020.

DINAMARCO, Cândido Rangel. Instituições de Direito Processual Civil. Vol. I. 8. Ed. São Paulo: Malheiros. 2016.

DINAMARCO, Cândido Rangel. A nova era do processo civil. São Paulo: Malheiros. 2003.

FIGUEIRA JUNIOR, Joel Dias. “Desjudicialização da Execução Civil”. Disponível em https://www.migalhas.com.br/depeso/330308/desjudicializacao-da-execucao-civil Consulta realizada em 08/07/2020.

GOLDBERG, Stephen B. SANDER, Frank E. A. ROGERGS, Nancy H. COLE, Sarah Rudolph. Dispute Resolution. 4. Ed. Nova York: Aspen Publishers. 2003.

GRECO, Leonardo. Instituições de Processo Civil. Vol. 1. Rio de Janeiro: GEN Forense. 2015.

GRECO, Leonardo. “As garantias fundamentais do processo na execução fiscal”. In LOPES, João Batista. CUNHA, Leonardo José Carneiro da (coords). Execução Civil (aspectos polêmicos). São Paulo: Dialética. 2005.

GRINOVER, Ada Pellegrini. Ensaio sobre a processualidade, Fundamentos para uma nova teoria geral do processo. Brasília: Gazeta Jurídica.2018.

HILL, Flávia Pereira. “O procedimento extrajudicial pré-executivo (Pepex): reflexões sobre o modelo português, em busca da efetividade da execução no Brasil”. In MEDEIROS NETO, Elias Marques de. RIBEIRO, Flávia Pereira. Reflexões sobre a Desjudicialização da Execução Civil. Curitiba: Juruá. 2020. pp. 305-322.

HILL, Flávia Pereira. PINHO, Humberto Dalla Bernardina de. "Inventário Judicial ou extrajudicial; separação e divórcio consensuais por escritura pública - primeiras reflexões sobre a Lei n. 11.441/07”. Revista Dialética de Direito Processual. V. 50. Maio-2007. pp. 42-59. 
HILL, Flávia Pereira. "A desjudicialização do procedimento de registro tardio de nascimento. Inovações trazidas pela lei federal n. 11.790/08". Revista Eletrônica de Direito Processual. V. 3. Ano 3. Jan-Jun 2009. pp. 123-133.

HILL, Flávia Pereira. “Considerações sobre a cooperação jurídica internacional no novo Código de Processo Civil”. MACÊDO, Lucas Buril. PEIXOTO, Ravi. FREIRE, Alexandre. Coleção novo CPC Doutrina Selecionada. Vol. 1. Parte Geral. 2. Ed. Salvador: Editora Jus Podivm. 2016. pp. 743-766.

HILL, Flávia Pereira. "Mediação nos cartórios extrajudiciais: desafios e perspectivas". Revista Eletrônica de Direito Processual. Volume 19, número 3. Set/dez 2018. pp. 296-323.

HILL, Flávia Pereira. “A cooperação jurídica internacional no Código de Processo Civil de 2015”. In Cooperação Internacional. ZANETI JUNIOR, Hermes. RODRIGUES, Marco Antonio dos Santos (Coords). Ed. Salvador: Jus Podivm. 2019. pp. 137-165.

HILL, Flávia Pereira. "Desjudicialização da Execução Civil: Reflexões sobre o Projeto de Lei No 6.204/2019”. Revista Eletrônica de Direito Processual. Volume 21, número 3. Setembro-Dezembro de 2020. Pp. 165-206.

HILL, Flávia Pereira. "Passado e futuro da mediação: perspectiva histórica e comparada". Revista de Processo. vol. 303/2020. pp. 479 - 502. Maio 2020.

HILL, Flávia Pereira. Lições do isolamento: reflexões sobre Direito Processual em tempos de pandemia. Rio de Janeiro: edição do autor 2020.

HILL, Flávia Pereira. "A desjudicialização e o necessário incremento da cooperação entre as esferas judicial e extrajudicial" In: ALVES, Lucelia de Sena. SOARES, Carlos Henrique. FARIA, Gustavo de Castro. BORGES, Fernanda Gomes e Souza (Orgs). 4 anos de vigência do Código de Processo Civil de 2015.1 ed. Belo Horizonte: D’Plácido, 2020, v.1, pp. 173-204.

LOUREIRO, Luiz Guilherme. Registros Públicos. Teoria e Prática. 3. Ed. São Paulo: GEN Método. 2012.

MANCUSO, Rodolfo de Camargo. A resolução dos conflitos e a função judicial no contemporâneo estado de Direito. 2. Ed. São Paulo: Revista dos Tribunais. 2013.

MARQUES, José Frederico. Instituições de Direito Processual Civil. Vol. I. Campinas: Millennium. 2000. 
MOREIRA, José Carlos Barbosa. Temas de Direito Processual Civil. $\sigma^{a}$ série. Rio de Janeiro: Forense. 1997.

OLIVEIRA, Carlos Alberto Alvaro de. Doformalismo no processo civil. São Paulo: Saraiva. 2003. pp. 108-109.

OLIVEIRA, Daniela Olímpio de. "Uma releitura do princípio do acesso à justiça e a ideia da desjudicialização". Revista Eletrônica de Direito Processual. Volume 11. Pp. 6798.

PASSOS, José Joaquim Calmon de. "O problema do acesso à justiça no Brasil. Revista de Processo". Revista de Processo. vol. 39/1985. Jul-Set 1985. pp. 78 - 88.

PASSOS, José Joaquim Calmon de. Direito, poder, justiça e processo. Rio de Janeiro: Forense. 2000.

PINHO, Humberto Dalla Bernardina de. "A releitura do princípio do acesso à justiça e o necessário redimensionamento da intervenção judicial na resolução dos conflitos na contemporaneidade”. In Revista Jurídica Luso-brasileira. Ano 5. Número 3. 209. pp. 791- 830.

PINHO, Humberto Dalla Bernardina de. HILL, Flávia Pereira. “A nova fronteira do acesso à justiça: a jurisdição transnacional e os instrumentos de cooperação internacional no CPC/2015”. Revista Eletrônica de Direito Processual. Volume 18, número 2. MaioAgosto 2017. pp. 261-296.

PINHO, Humberto Dalla Bernardina de. PORTO, José Roberto Mello. “A desjudicialização enquanto ferramenta de acesso à justiça no CPC/2015: a nova figura da usucapião por escritura pública”. Revista Eletrônica de Direito Processual. Volume 17, número 2. Julho-Dezembro 2016. pp. 320-353.

ROGERS, N. BORDONE, R. SANDER, F. MCEWEN, C. Designing Systems and Processes for managing disputes. 2. Ed. New York: Wolters Kluwer. 2019. E-book. 